III

\title{
KOMERCJALIZACJA TACIERZYŃSTWA. RELACJA OJCA Z DZIECKIEM NA TLE DZIAŁAŃ MARKETINGOWYCH
}

\begin{abstract}
Kamil Janowicz, Aleksandra Jasielska, Komercjalizacja tacierzyństwa. Relacja ojca z dzieckiem na tle działan marketingowych [Commercialization of fatherhood. The relationship of the father with the child against the background of marketing activities] edited by L. Bakiera, M. Obrębska, "CZłowiek i Społeczeństwo" vol. Ll: Blisko czy na dystans? Psychologiczne aspekty relacji międzyludzkich [Closely or distantly? The psychological aspects of interpersonal relations], Poznań 2021, pp. 79-100, Adam Mickiewicz University. ISSN 0239-3271, https://doi.org/10.14746/cis.2021.51.4.
\end{abstract}

The last decades brought us dynamic changes in patterns of fatherhood. It is related both to expectations toward men, and their daily functioning itself. However, the role of a father is less often commercialized than the role of a mother. In line with that, commercials and marketing activities are less often addressed to fathers than to mothers. This paper is addressed to the potential grounds of this state of affairs, and the description of the new phenomenon - dadvertising. The possible manners of profiling marketing activities including fathers as primary recipients will be presented and discussed concerning findings of studies from the field of family psychology, sociology of the family, and a few existing studies aimed at commercials addressed to fathers. The abovementioned issues will be illustrated by examples of single commercials and marketing campaigns, in which protagonists or recipients were fathers.

Keywords: fathering, commercialization of parenthood, advertising, marketing

Kamil Janowicz, Uniwersytet im. Adama Mickiewicza w Poznaniu, Wydział Psychologii i Kognitywistyki, ul. Szamarzewskiego 89AB, 60-568 Poznań, e-mail: kamil.janowicz@amu.edu.pl, ORCID: https://orcid. org/0000-0002-6193-5331.

Aleksandra Jasielska, Uniwersytet im. Adama Mickiewicza w Poznaniu, Wydział Psychologii i Kognitywistyki, ul. Szamarzewskiego 89AB, 60-568 Poznań, e-mail: aleksandra.jasielska@amu.edu. pl, ORCID: https://orcid.org/0000-0001-7874-5086. 


\section{Wprowadzenie}

Dorosłość to czas funkcjonowania w wielu rolach społecznych. Trzema głównymi obszarami zaangażowania, wokół których skupia się znaczna część życia dorosłych ludzi, są: praca zawodowa, bliski związek romantyczny i rodzicielstwo (Gurba, 2009; Havighurst, 1981). Funkcjonowanie w tych rolach wiąże się z korzystaniem z licznych sprzętów i usług - zrozumiałe zatem, że ich producenci i dostawcy starają się znaleźć różne drogi, aby przekonać potencjalnych klientów do skorzystania z ich propozycji. Ostatnie lata przyniosły wzrost zainteresowania rodzicami jako potencjalnymi adresatami przekazów reklamowych czy działań marketingowych. Jest to uzasadnione m.in. postrzeganiem dzieci jako projektu biograficznego, którego powodzenie uzależnione jest od nakładów finansowych poniesionych przez rodziców (Halawa, 2006: 54; por. dziecko jako inwestycja - Jasielska i Maksymiuk, 2010b).

Głównym celem niniejszego tekstu jest analiza przekazów reklamowych, których adresatami i bohaterami są ojcowie. Zostanie ona dokonana w odniesieniu do zjawiska komercjalizacji rodzicielstwa. Na podstawie badań psychologicznych i socjologicznych dotyczących sposobu pełnienia roli rodzicielskiej przez mężczyzn i przemian we wzorcach ojcostwa przedstawione zostaną również możliwe przyczyny mniejszego zainteresowania ojcami jako grupą docelową działań marketingowych, a także propozycje profilowania takich działań uwzględniające ojców jako ich głównych adresatów.

\section{„Komercjalizacja” rodzicielstwa}

Rodzice stanowią ogromną część społeczeństwa, a samo rodzicielstwo to jeden z głównych obszarów funkcjonowania osób dorosłych. Okres największej intensywności związanej z pełnieniem tej roli obejmuje zazwyczaj od kilkunastu do nawet 30-40 lat (w zależności od liczby posiadanego potomstwa) i przypada głównie na okres wczesnej i średniej dorosłości (między 25. a 60. r.ż.). Specyfika pełnienia roli rodzicielskiej zmienia się na kolejnych etapach życia rodziny (Ostoja-Zawadzka, 1997). Rodzice na przestrzeni tych lat podejmują wiele decyzji konsumenckich dotyczących zakupu produktów i usług związanych z byciem rodzicem, np. sprzętów, mebli, ubrań, jedzenia, elektroniki, wyjazdów wakacyjnych itp. 
Strategiczne działania marketingu polegają na pozyskiwaniu kolejnych specyficznych grup konsumentów. Dzięki temu powstał np. marketing senioralny czy kindermarketing (Jasielska i Maksymiuk, 2010a). Z tego samego powodu dla osób dorosłych posiadających dzieci został stworzony marketing familijny (rodzinny) czy parentingowy (rodzicielski). Dzieje się tak, ponieważ bycie rodzicem oraz opieka i wychowywanie potomstwa nabierają wartości rynkowej, określanej jako „komercjalizacja rodzicielstwa” (Jasielska i Maksymiuk, 2011). W procesie tym psychologiczna interpretacja wejścia w rolę rodzica jako krytycznego zadania rozwojowego dla okresu wczesnej dorosłości (Havighurst, 1981) jest transponowana na język wolnego rynku, a specjaliści od marketingu z powodzeniem wykorzystują wiedzę z zakresu psychologii do analizy życia rodzica, aby wskazać zasadnicze momenty i przygotować produkty odpowiadające związanym z nimi potrzebom rodziców. W chwili narodzin (a także planowania czy poczęcia) dziecka dorosły jest identyfikowany jako członek określonej grupy konsumenckiej. Przykładowo jedna z segmentacji konsumentów uwzględnia m.in. tzw. DEWKS (ang. dual earners with kids), czyli rodziny z dziećmi, w których oboje małżonkowie pracują, i przeciwnych im DINKS (ang. double income, no kids) - pracujące zawodowo pary, które nie posiadają dzieci (Jaworowski i Polański, 2004). Istnieje też kilka segmentacji rodziców określających udział poszczególnych grup w rynku (Szlendak, 2005: 40). Jedna z najbardziej aktualnych klasyfikacji oparta na wartościach, jakimi kierują się rodzice, wybierając produkty dla dzieci, oraz ich zaangażowaniu w trendy i technologie, z jakich korzystają, wyłoniła rodziców: Slow, Pilnych, Minimalistycznych, New Tech i Niezależnych (Raport Czy nowe technologie wychowujq dzieci Milenialsów?, 2016¹). Z kolei badanie „Family Power” (Raport Family Power, 2019²) poświęcone polskiej rodzinie wskazało na następujące typy rodziców: Wspierających, Tradycyjnych, Niekonsekwentnych, Delegujących i Zadaniowych. Jednoznaczna konkluzja specjalistów od marketingu brzmi „kobiety ciężarne i młodzi rodzice są Świętym Graalem handlu detalicznego. Praktycznie nie istnieje grupa, która umożliwiałaby większe zyski, która byłaby bardziej głodna wszelkich produktów i niewrażliwa na ich cenę” (Duhigg, 2013: 269).

${ }^{1}$ Raport został oparty na wynikach badania sondażowego zrealizowanego w dniach 29.02-3.03.2016 r. przez SW Research. https://branzadziecieca.pl/wp-content/uploads/2016/04/ raport-rodzice-2016.pdf (dostęp: 12.11.2020).

2 Raport wykonany przez IQS Research Think Forward, autorskie badanie IQS poświęcone polskim rodzinom zrealizowane w okresie lipiec-wrzesień 2019 r. https:// marketingprzykawie.pl/espresso/polskie-rodziny-lupa-iqs/ (dostęp: 27.04.2021). 
W badaniach marketingowych rodziców traktuje się jako grupę homogeniczną, natomiast w praktyce większość działań koncentruje się na sile nabywczej mam (ang. Mom Power - Schor, 2004: 62). I choć niekiedy traktuje się np. zaangażowanie ojca jako punkt odniesienia dla opisu konsumpcji mam (por. typologia matek według LeoShe - Solomon, 2009: 488), to dominują działania komercyjne skierowane na konsumenta vel klienta „o czterech oczach i czterech nogach” (ang. four-eyed, four-legged consumer), którego siła nabywcza opiera się na harmonijnej koegzystencji matki i dziecka (Schor, 2004). W związku z tym dostępne są m.in. opracowania branżowe (np. Bailey, 2008; Siegel, Coffey i Livingson, 2005), pozycjonowanie rynkowe (identyfikujące np. „Alfamamę” - Lewandowski, 2007; „Smart shoperkę” - Sewera, 2013; „Momfluencerkę” - Szpak, 2019); rady (np. jak angażować „Matki milenijne” w działanie marek - Sewera, 2013), przeznaczone dla marketingu kierowanego do mam. Chociaż w odniesieniu do matek dokonano kilku analiz ich zachowań konsumenckich oraz ich profilowania (por. Raport z badań Matki 2013, 2013), brakuje analogicznych opracowań w odniesieniu do ojców. Matki są głównymi adresatkami także w przypadku wspomagających rodzicielstwo aplikacji, których analiza dokonana przez Anilę Virani, Lindę Duffett-Leger i Nicole Letourneau (2019) wykazała, że żadna z nich nie była skierowana do ojców.

Podsumowując, na przestrzeni ostatnich lat obserwuje się rosnące zainteresowanie rodzicami jako grupą konsumencką. Istotny jest jednak fakt, że nieporównywalnie więcej uwagi poświęcano dotychczas matkom. Również przekazy reklamowe częściej kierowane są do nich i to one są ich bohaterkami. W związku z tym w kolejnej części artykułu przedstawione i przeanalizowane zostaną możliwe przyczyny poświęcania ojcom mniejszej uwagi przez marketingowców.

\section{Pomijanie ojca-konsumenta - możliwe przyczyny}

Jak już wspomniano, ojcowie rzadziej od matek są adresatami i bohaterami kampanii reklamowych. Wydaje się, że decydować o tym mogą: różnice w zakresie łączenia roli płciowej z rolą rodzinną u kobiet i mężczyzn, funkcjonujące w naszym społeczeństwie stereotypy płciowe, podział zadań w rodzinie oraz uwarunkowania prawne.

Po pierwsze, wskazuje się, że w naszym społeczeństwie rola rodzicielska (matka/ojciec) jest w przypadku mężczyzn słabiej połączona z rolą płciową niż w przypadku kobiet (Wojciszke, 2002). Innymi słowy, według 
dominującego dyskursu bycie matką bardziej dookreśla i definiuje kobietę, niż bycie ojcem dookreśla mężczyznę. Znajduje to swoje odzwierciedlenie w procesie socjalizacji. W działaniach wychowawczych rozdzielenie roli rodzinnej od roli płciowej następuje szybciej w przypadku wychowywania chłopców (Wojciszke, 2002). Rodzicielstwo zazwyczaj jest wyżej wartościowane przez kobiety niż mężczyzn, którzy swoją tożsamość w mniejszym stopniu budują w odniesieniu do ról związanych z życiem rodzinnym (Maher, Dever, Curtin i Singleton, 2004; Marsiglio, Hutchinson i Cohan 2000). Dotyczy to także antycypacji własnej przyszłości - rodzicielstwo częściej było centralnym tematem narracji o swoim dorosłym życiu w wypowiedziach kobiet niż mężczyzn (Janowicz, 2018). Pomimo zmian w polskim społeczeństwie nadal silnie zakorzenione w świadomości kobiet i mężczyzn są stereotypy dotyczące ról płciowych, wedle których to kobieta głównie zajmuje się domem i dziećmi, a mężczyzna pracuje zawodowo na utrzymanie rodziny (Szulich-Kałuża i Wadowski, 2014). Można zatem przewidywać, że odwoływanie się do roli rodzicielskiej będzie mniej skuteczne w nakłanianiu mężczyzn niż kobiet do dokonania zakupów. Nie można jednak zapominać, że wzorce te ulegają zmianie i na przestrzeni ostatnich lat rośnie odsetek mężczyzn bardziej angażujących się w ojcostwo i wyżej je wartościujących (Bakiera, 2014), natomiast dla kobiet coraz ważniejsze stają się rozwój zawodowy i kariera. W odniesieniu do tego można się spodziewać wzrostu zainteresowania mężczyznami-ojcami ze strony marketingowców.

Drugą z możliwych przyczyn, dla których ojcowie rzadziej niż matki są adresatami reklam, jest niesymetryczny rozkład obowiązków w gospodarstwie domowym. Wyniki badań wskazują, że rodzicielskie obowiązki w większym stopniu spoczywają na matkach - częściej zajmują się one opieką nad dziećmi i ich pielęgnacją (mycie, ubieranie, przewijanie, karmienie itp.), przygotowywaniem dla nich posiłków, wizytami u lekarza, załatwianiem spraw w szkole i/lub przedszkolu oraz pomocą w nauce (Włodarczyk, 2014). Natomiast zaangażowanie ojców było większe niż matek w przypadku uprawiania sportu, a czas poświęcany na zabawę z dzieckiem zazwyczaj był podobny wśród matek i ojców. Analitycy z Nationale-Nederlanden (Powrót taty, 2019) także przyjrzeli się temu, w jakim stopniu ojcowie angażują się w różne domowe aktywności. Największe zaangażowanie ojcowie deklarowali w odniesieniu do uprawiania sportu, wspólnej zabawy i spacerów. Spora część z nich (ok. 2/3) deklarowała, że często pomaga dzieciom w nauce czy też przygotowuje dla nich posiłki do szkoły. Bardzo często realizowaną, przynajmniej w deklaracjach ojców, aktywnością 
było też wożenie dzieci do szkoły oraz na różne zajęcia dodatkowe. Warto podkreślić przy tej okazji, że w odniesieniu do większości wspomnianych powyżej aktywności matki oceniały, że mężczyźni zajmują się tym rzadziej, niż to deklarują. Dość często ojcowie deklarowali ponadto, że rozmawiają z dziećmi na tematy związane z finansami. Co ciekawe, aż 71\% badanych ojców deklarowało, że po narodzinach dziecka ograniczyli swoje własne wydatki, aby więcej środków przeznaczyć na potrzeby dzieci. Może to wskazywać na pewną gotowość do ponoszenia dodatkowych kosztów związanych z opieką i wychowaniem dziecka. Niecałe $60 \%$ badanych mężczyzn (w porównaniu do 49\% kobiet) deklarowało, że na bieżąco odkłada oszczędności z myślą o przyszłości dziecka. Często decydowali się oni również na wykupienie dodatkowej polisy na życie, aby zapewnić rodzinie większe bezpieczeństwo. W badaniach dotyczących wyobrażeń na temat siebie jako rodzica w przyszłości obawy związane z sytuacją finansową rodziny częściej deklarowali mężczyźni niż kobiety (Janowicz, 2018). Warto też wspomnieć wyniki badania, w którym uczestnikom zadano pytanie „Kto najczęściej podejmuje decyzje o zakupach dla dziecka?”. 63,2\% respondentów odpowiedziało, że decydują razem, 35,8\% - że przede wszystkim żona/partnerka, a zaledwie $1 \%$ - że przede wszystkim mąż/ partner (Szpak, 2019).

Podsumowując, można stwierdzić, że kobiety i mężczyźni z różną częstotliwością angażują się w poszczególne obszary życia domowego i rodzinnego, także te dotyczące zakupów dla dzieci. Ojcowie częściej zajmują się sprawami związanymi ze wspólną z dziećmi aktywnością fizyczną, edukacją finansową oraz wożeniem dzieci. Zdecydowanie rzadziej natomiast angażują się w czynności opiekuńczo-pielęgnacyjne i wizyty lekarskie. Rzadziej też decydują o zakupach produktów dla dzieci. Z perspektywy skuteczności działań marketingowych można by zatem założyć, że reklamy kierowane do ojców częściej mogłyby dotyczyć następujących usług i produktów: sprzętu sportowo-turystycznego, samochodu, usług finansowych (lokaty, polisy, ubezpieczenia), a rzadziej pieluszek, jedzenia, środków czystości lub leków dla dzieci.

Na większe zainteresowanie twórców kampanii reklamowych matkami niż ojcami wpływać może także to, iż przeważająca część rodzin niepełnych to takie, w których matka sprawuje główną opiekę nad dzieckiem (Gospodarstwa domowe i rodziny, 2014; Rydz, 2014). Dane Głównego Urzędu Statystycznego (Gospodarstwa domowe i rodziny, 2014) wskazują, że w przypadku decyzji o przyznaniu opieki sądy w 60\% sytuacji przyznają ją głównie matce. Zaledwie niecałe 5\% dzieci trafia głównie pod 
opiekę taty. Choć ojcowie i matki są równi w świetle prawa, to nierzadko wskazuje się, że sądy rodzinne bywają stronnicze na korzyść matek, gdy dochodzi do podziału pieczy rodzicielskiej. Wynika z tego, że w przypadku rodzin niepełnych dużo częściej są to gospodarstwa domowe kierowane przez kobiety, w związku z tym one częściej będą podejmowały decyzje dotyczące zakupu produktów i usług, co może skłaniać marketingowców do tego, aby to właśnie matki częściej czynić adresatkami przekazów reklamowych.

Należy przy tej okazji wspomnieć również o różnicach w zakresie urlopu, jaki oboje rodzice mogą otrzymać ze względu na opiekę nad dzieckiem. O ile od niedawna urlop rodzicielski może być dzielony między oboje rodziców, to nadal w zakresie urlopu poszczególnych rodziców mamy do czynienia z nierównością - urlop macierzyński (wyłącznie dla matki) to 20 tygodni, podczas gdy urlop ojcowski (wyłącznie dla ojca) to 2 tygodnie (Chełstowska i Zarzyńska, 2014). W związku z tym, ze względu na rozwiązania prawne, mężczyźni mają ograniczoną możliwość spędzania czasu z dzieckiem w pierwszych tygodniach i miesiącach jego życia, co może przekładać się na mniejsze ich zaangażowanie w czynności opiekuńczo-pielęgnacyjne (karmienie, kąpanie, przewijanie). Co za tym idzie, zrozumiałe jest, że reklamy związane z tymi produktami i usługami częściej kierowane są do matek.

Podsumowując, w odniesieniu do danych wskazujących na różnice w zakresie zaangażowania w rolę rodzicielską przez kobiety i mężczyzn oraz analizując funkcjonujące w polskim społeczeństwie wzorce socjalizacyjne i stereotypy płciowe, fakt, że twórcy reklam i działań promocyjnych częściej kierują je do matek niż do ojców, wydaje się częściowo uzasadniony. Można jednak przypuszczać, że tendencja ta będzie ulegała zmianie wraz z rozpowszechnieniem bardziej egalitarnych wzorców życia rodzinnego oraz idei zaangażowanego ojcostwa.

\section{Ojcowie jako adresaci i bohaterowie kampanii reklamowych}

Chociaż ojcowie rzadziej niż matki są adresatami i bohaterami kampanii reklamowych, nie oznacza to, że są całkowicie poza obszarem zainteresowania marketingowców. W tej części tekstu przedstawione zostaną wyniki dotychczasowych analiz w tym zakresie, a także wynikające z nich wnioski odnoszące się do sposobu przedstawiania ojców i samego tacierzyństwa w przekazach reklamowych. 
Ponieważ przedmiotem zainteresowania jest zjawisko nowe, to stosunkowo niewiele badań poświęconych jest działaniom marketingowym i kampaniom reklamowym kierowanym bezpośrednio do ojców, a nie pośrednio do rodziców. Zrealizowane badania można podzielić na dwie grupy: eksperymentów i analiz „wytworu”.

W pierwszej, zdecydowanie mniej licznej, obecne są badania realizowane zgodnie z metodologią nauk społecznych. W badaniach Stacey M. Baxter, Alicii Kulczynski i Jasminy Ilicic (2016) uczestnikom pokazano przygotowaną dla potrzeb eksperymentu reklamę prasową, która przedstawiała dziecko i opiekuna płci męskiej lub żeńskiej używającego płynu marki Huggies do kąpieli dziecka. W reklamie testowej znajdowała się aranżacja sugerująca, że dziecko „rozmawia” z opiekunem, np. „Tato [mamo], mój strój urodzinowy można prać tylko delikatnie”. Wyniki wskazują, że reklama przedstawiająca mężczyznę w roli opiekuna jest postrzegana pozytywnie, choć dla wielu osób wydaje się nietypowa. Mniej tradycyjni uczestnicy docenili przedstawienie ojca, które jest zgodne z ich własnymi przekonaniami, i akceptowali zaproponowaną zmianę w układzie społecznym. Z kolei bardziej tradycyjni kwestionowali kompetencje ojca i postrzegali jego zachowanie jako nietypowe. W badniach Chun-Tuan Chang i Minh-Hsuana Tunga (2015) manipulowano wizerunkiem międzypokoleniowym (m.in. samotny ojciec vs ojciec z synem) oraz przekazem dotyczącym miłości rodzicielskiej w reklamie imitującej rzeczywiste reklamy luksusowych zegarków. Dowiedziono, że takie odwołanie międzypokoleniowe może skutecznie poprawić wizerunek marki, skłonić do zakupu oraz efektywnie promować nawet mniej znaną markę.

Kelly Cowart (2019) przeprowadziła badanie, w którym uwzględniła takie zmienne indywidualne, jak retrospektywna ocena zaangażowania ojcowskiego oraz sentymentu ojca w kontekście marketingowym. Przygotowano reklamę nowej kuchenki mikrofalowej fikcyjnej marki Sonic dla mediów społecznościowych. Reklama zawierała wizerunek ojca (lub matki) oraz przekaz, który w ojcowskiej wersji brzmiał „Stwórz pyszne danie jak Twój tato. Twój tato będzie dumny”. Wyniki pokazały, że osoby, które wskazywały na niskie zaangażowanie ojca i negatywne uczucia ojcowskie, wyżej oceniały reklamę z odniesieniem matczynym bądź były bardziej responsywne wobec takiej reklamy. Ponadto uczestnicy badania, którzy wspominali swoich ojców jako nieobecnych czy niezaangażowanych oraz mieli nieprzychylny sentyment wobec ojców, byli także bardziej skłonni do preferowania reklamy z odniesieniem macierzyńskim niż ojcowskim. Ta zaobserwowana negatywna postawa osób „zaniedbanych przez ojca” 
wobec przekazów reklamowych z jego udziałem powinna sugerować reklamodawcom zachowanie ostrożności podczas projektowania kampanii z odniesieniami ojcowskimi i przekazami ukierunkowanymi na inne osoby, zwłaszcza gdy są kierowane do konsumentów płci żeńskiej. Przywołane badania wskazują, że manipulowanie wizerunkiem „nowego taty” w przekazach reklamowych jest odbierane pozytywnie przez potencjalnych konsumentów, ale tylko wtedy, kiedy nie rozważamy heterogeniczności tej grupy, uwzględniając w jej opisie zmienne psychologiczne (por. Ho, Lim i Camerer, 2006).

Druga grupa badań dotyczących marketingu ojcowskiego obejmuje analizę wytworów, czyli przeprowadzoną ze względu na różne aspekty specyfikację reklam czy to prasowych, czy telewizyjnych już zrealizowanych. Uporządkowane chronologicznie analizy pokazują m.in., że w materiałach reklamowych dotyczących rodziny w magazynach dla kobiet z lat 1950-2010 z biegiem czasu obraz ojca transformuje z jednoznacznie patriarchalnego opiekuna, obrońcy rodziny, w wielowymiarowy, bardziej niejednoznaczny i mniej oczywisty pod względem roli w rodzinie (Marshall, Davis, Hogg, Schneider i Petersen, 2014). Z kolei analiza reklam z lat 2007-2008 sugeruje, że o ile kobiety są pokazywane w mniej stereotypowy sposób, to męskie portrety wciąż odzwierciedlają bardziej tradycyjną perspektywę (Gentry i Harrison, 2010). Postęp w zmianie wizerunkowej ojca został zidentyfikowany jako niewielki i powolny dla reklam prezentowanych w najlepszym czasie antenowym w roku 2008. Kiedy mężczyźni są pokazani jako ojcowie opiekuńczy, ich zaangażowanie w aktywności z dziećmi ogranicza się do zabawy (Tsai, 2010). Analiza reklam emitowanych w Polsce w latach 2005-2013 wskazuje na równoczesną obecność kilku wizerunków ojca, np. ojca-głowy rodziny, ojca-przyjaciela dziecka (Rejowska, 2015). W tym, jak wizerunek ojca jest kreowany w reklamie, mogą mieć udział wzorce kulturowe uwzględniające wymiary wertykalne, akcentujące status i horyzontalnie zorientowane na równość w manifestowanych wartościach. Analiza reklam z lat 2014-2015 pokazała, że w zorientowanej horyzontalnie Szwecji ojcowie są częściej przedstawiani w rolach neutralnych lub odwróconych płciowo. Przeciwnie zaś w zorientowanej wertykalnie Wielkiej Brytanii, ojców przedstawiano stereotypowo jako żywicieli rodziny i liderów (Tian, 2019). Tymczasem diagnoza trendów w reklamie produktów dla rodziny przeprowadzona w roku 2019 wskazuje, że na przestrzeni ostatnich pięciu lat obserwuje się wzrost reklam ojcowskich (ang. dadvertisements) (Leader, 2019: 77). Na podstawie zreferowanych danych wyłoniono kilka modelowych wizerunków ojca uwzględnionych na rysunku 1. 


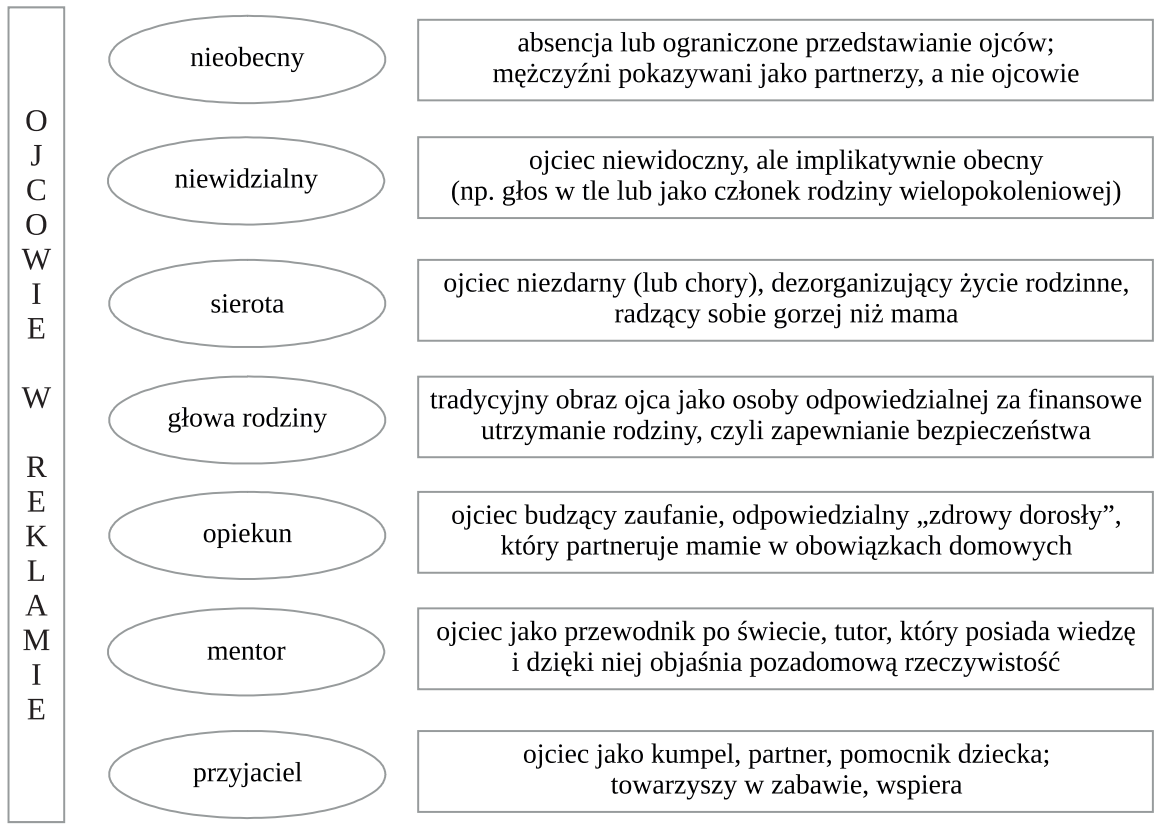

Rysunek 1. Wizerunki ojca w reklamie

Źródło: opracowanie własne na podstawie Marshall i in., 2014; Rejowska, 2015; Tian, 2019.

Warto podkreślić, że znaczna część tych wizerunków dotyczy sposobu budowania przez ojców relacji ze swoimi dziećmi. W przypadku ojców nieobecnych i niewidzialnych można powiedzieć, że relacja ta jest raczej słaba, a ojciec nie angażuje się w kontakt z dzieckiem. Również w przypadku wizerunku ojca jako głowy rodziny aspekt relacyjny nie jest szczególnie istotny. Nabiera on pewnego znaczenia przy przedstawieniach ojca jako opiekuna, choć i w tym przypadku nie jest najważniejszy. Charakter relacji ojca z dzieckiem stanowi natomiast centralny punkt w przypadku wizerunków ojca jako mentora i przyjaciela. W pierwszym przypadku ojciec jawi się jako mistrz, przewodnik po świecie. Ojciec-mentor wprowadza dziecko w świat dorosłych, tłumaczy rzeczywistość, wspiera rozwój dziecka. Relacja między ojcem i dzieckiem we wzorcu ojca-przyjaciela silniej skupia się na wymianie emocjonalnej, jest bardziej pozioma. W skrajnym przypadku wiąże się z ukazaniem ojca i dziecka jako równorzędnych partnerów, co mogłoby prowadzić do zaburzeń w strukturze systemu rodzinnego (Liberska i Matuszewska, 2014). 


\section{Zmiana (nie tylko) wizerunkowa taty}

Przedstawione sposoby ukazywania ojców w reklamach są bardzo niejednorodne, co koresponduje z zachodzącymi zmianami społecznymi w zakresie wzorców realizowania roli ojcowskiej (Bakiera, 2014). Od lat pięćdziesiątych ubiegłego wieku jesteśmy świadkami fragmentaryzacji stabilnego dotąd skryptu kulturowego męskości i ojcostwa (Bell, 2013; Marshall i in., 2014). Przekłada się to na życie rodzinne, w którym można zaobserwować jednocześnie dekonstrukcję patriarchalizmu i depolaryzację rodzicielstwa oraz rozwój partnerstwa (por. Leader, 2019). W związku z tym granica między dwoma wyrazistymi modelami ojcostwa (tradycyjnym i nowoczesnym) ulega zatarciu (Bell, 2013; Kłosińska, 2015). „Srogiego ojca”, którego rola ogranicza się głównie do zapewnienia rodzinie bezpieczeństwa finansowego, zastępuje „opiekuńczy tata”, który sam dostrzega, że ojcostwo jest istotną rolą w jego życiu i świadomie angażuje się w wychowanie dzieci.

Odnosząc się do wyróżnionych przez Arlie Hochschilda (1989) podstawowych paradygmatów podziału pracy w rodzinie, uzasadnione jest stwierdzenie, że we współczesnym dyskursie społecznym można równolegle odnaleźć odwołania do każdego z nich - zarówno do paradygmatu tradycyjnego (w którym mężczyźni powinni zapewnić rodzinie zabezpieczenie finansowe, podczas gdy kobiety powinny skupiać się na pracach domowych i obowiązkach związanych z wychowywaniem dzieci), tranzycyjnego (w którym akceptuje się udział kobiet i mężczyzn w płatnej i nieodpłatnej pracy, ale nadal przyjmuje się, że mężczyźni powinni skupiać się przede wszystkim na zarabianiu na życie, a kobiety zajmować się prowadzeniem domu), jak i trendowego, zwanego też egalitarnym (zakładającego, że kobiety i mężczyźni dzielą się obowiązkami domowymi i pracą równomiernie). To ścieranie się konkurencyjnych wzorców ojcostwa znajduje swoje odzwierciedlenia w spostrzeganych przez młodych dorosłych, zarówno kobiety, jak i mężczyzn, oczekiwaniach wobec współczesnych ojców (Janowicz, 2017). Różne perspektywy w odmienny sposób ukazują priorytetowe aspekty roli ojca (nierzadko sprzeczne), co prowadzi do tego, że oczekiwania wobec ojców są niespójne, a to utrudnia mężczyznom odnalezienie się w nowej dla nich roli (Bakiera, 2014; Fein, 1978; Kwaśniewski i Masłowski, 2016). Ten proces renegocjowania wzorców ojcostwa znajduje swoje odzwierciedlenie także w kampaniach reklamowych. 


\section{Reklamowe sposoby realizowania roli ojcowskiej - cases studies}

Uwzględniając przedstawioną wcześniej różnorodność w zakresie pełnienia przez mężczyzn roli ojca, chcielibyśmy przedstawić możliwe sposoby „profilowania” działań marketingowych do ojców. Propozycje te zostaną zobrazowane zrealizowanymi już polskimi i zagranicznymi kampaniami reklamowymi.

W pierwszej kolejności warto odwołać się do Dnia Ojca jako okazji stymulującej do uczynienia ojców bohaterami przekazu reklamowego. Zaobserwowano dwie grupy reklam związanych z tym świętem. Pierwszy typ skierowany jest do dzieci (również tych dorosłych) i zachęca do tego, aby sprezentować swojemu tacie konkretny przedmiot. Druga grupa reklam nie prezentuje żadnego konkretnego produktu, ale raczej jest nakierowana na podkreślenie znaczenia ojca w życiu człowieka - reklamy z tej grupy często zawierają mocno poruszający emocjonalny przekaz, np. dzieci mówiące komplementy swoim ojcom albo opowiadające o tym, co w nich cenią. Ten typ bardziej skupia się na podkreśleniu wagi relacji ojciec-dziecko. Relacja ta i opowieść o niej często są główną osią fabularną reklamy. Informacja o marce stojącej za tą kampanią pojawia się zazwyczaj na koniec materiału ${ }^{3}$.

Niektóre badania wskazują, że ojcowie mają większą niż matki skłonność do stereotypizacji płciowej swoich dzieci (Endendijk i in., 2013). Przejawia się to m.in. tendencją do wybierania bardziej stereotypowych zabawek (np. lalki dla córek, autka dla synów) i aktywności (np. zabawa w dom z córką, zabawa w plac budowy z synem). Można by przewidywać, że ten stan rzeczy będzie znajdował swoje odzwierciedlenie w reklamach. Wśród reklam dotyczących różnych zabawek nie odnaleziono jednak takich, w których udział braliby rodzice. Zidentyfikowano natomiast kampanię społeczną ze Stanów Zjednoczonych zachęcającą ojców do spędzania czasu z córkami pod hasłem „Play Catch with Her”. W spocie przeplatają się opowieści dziewcząt o tym, jak ważne były dla nich zabawy z ojcami,

${ }^{3}$ https://www.youtube.com/watch?v=pr4CRc_h-9w\&feature=emb_logo (dostęp: 10.06.2020); https://www.youtube.com/watch?v=R0-5HORRXU0\&feature=emb_logo (dostęp: 10.06.2020); https://www.youtube.com/watch?v=pCtrScg9tn4\&feature=emb_logo (dostęp: 10.06.2020); https://www.youtube.com/watch?v=zhPklt9nYas\&feature=emb_logo (dostęp: 10.06.2020). 
oraz nagrania ojców bawiących się z córkami w mniej stereotypowy sposób (np. grających w piłkę nożną i futbol amerykański) (por. Cowart, 2019).

Wątek relacji ojciec-córka obecny jest także w reklamie samochodu marki Škoda Rapid - „ojciec wchodzi w rolę przyjaciela swojej córki i udziela jej pomocy. Mężczyzna opowiada, że «jego księżniczka» miała szesnaste urodziny. W spocie reklamowym angażuje się w ich zorganizowanie: przygotowuje ogród na przyjęcie gości, zajmuje się też nagłośnieniem, które niestety psuje się w trakcie imprezy, lecz zaradny rodzic wykorzystuje swoje auto, aby móc odtwarzać muzykę. Film przedstawia mężczyznę jako bohatera, a obraz ten dopełnia hasło «Rycerz nie zawsze przyjeżdża na białym rumaku». Ponadto należy zwrócić uwagę na silną więź łączącą rodzica i dziecko, ponieważ ojciec jest obecny na imprezie urodzinowej dorastającej córki” ${ }^{5}$ (Rejowska, 2015: 359). Reklama ta częściowo przełamuje stereotypowe przedstawienie ojca jako zdystansowanego (jest on tutaj w dobrej i bliskiej relacji z nastoletnią córką), częściowo jednak bazuje na dosyć konwencjonalnym sposobie postrzegania „ojca jako bohatera/rycerza dla swojej córki”. Podsumowując, nie odnaleziono reklam, które bezpośrednio bazowałyby na raportowanej w badaniach skłonności mężczyzn do silniejszego (w porównaniu z matkami) stereotypizowania płciowego dzieci. Przeciwnie, przedstawione kampanie przełamywały ten wzorzec, odnosząc się do relacji ojciec-córka.

Druga grupa reklam wiąże się z poruszonym już wcześniej zagadnieniem dotyczącym odmiennego zaangażowania ojców i matek w różne aktywności z dziećmi. Spośród wielu form działania wydaje się, że obszarem, w który ojcowie częściej się angażują, jest uprawianie sportu, aktywność fizyczna i wyprawy turystyczne (szczególnie te „z dreszczykiem emocji”, związane z jakimś wyzwaniem albo sportem wyczynowym) (Włodarczyk, 2014). Do motywu wspólnej aktywności fizycznej odwołuje się m.in. kampania przytoczona wcześniej. Wśród reklam odnoszących się do wspólnego uprawiania sporu, wyjazdów i przygód ojców z dziećmi wskazać można np. te promujące zakup samochodu marki Mercedes pod hasłem „Na poszukiwanie jakiej przygody zabierzesz swoją rodzinę?”6 - całość kampanii oznaczona jest też hashtagiem \#4Fathers. Warto podkreślić, że ta kampania łączy dwa wspomniane już obszary częściej przypisywane

${ }^{4}$ https://www.youtube.com/watch?v=YTY9g8_05Gs (dostęp: 10.06.2020).

${ }^{5}$ https://www.youtube.com/watch?v=6AJHuK2g7h (dostęp: 24.11.2020).

${ }^{6}$ https://www.youtube.com/watch?v=lVJURoLHPHI (dostęp: 10.06.2020); https:// www.youtube.com/watch?v=qV95WwHnXzQ (dostęp: 10.06.2020); https://www.youtube. com/watch?v=r9kseOMYHl8 (dostęp: 10.06.2020). 
ojcom - wspólną aktywność fizyczną oraz pełnienie roli kierowcy. Odwołanie do pierwszego z nich (sport, przygody, turystyka) ma zwiększać motywację do zakupy produktu (auta) związanego z drugim z tych obszarów. Przy tej okazji warto wspomnieć, że reklamy samochodów rodzinnych wydają się skierowane głównie do mężczyzn ${ }^{7}$ - to oni zawsze dzierżą kierownicę, bezpiecznie przewożą partnerkę i dzieci oraz dbają o komfort podróżujących. W świetle przekazu reklamowego zakup wybranego modelu to przejaw troski i odpowiedzialności ze strony mężczyzny-ojca. Nie znaleziono żadnej reklamy auta, w której to kobieta (mama) siedziałaby za kierownicą, a mąż był na fotelu pasażera.

Zdecydowanie rzadziej ojcowie są zaangażowani w czynności opiekuńczo-pielęgnacyjne (Powrót taty, 2019; Włodarczyk, 2014). Trudno znaleźć reklamy takich produktów jak pieluszki czy jedzenie dla niemowląt, których adresatami byliby ojcowie. Do niedawna reklamy dotyczące dbania o zdrowie dziecka były zdominowane przez przekazy kierowane do mam ${ }^{8}$, lecz w ostatnim czasie pojawiło się kilka spotów, w których to ojcowie podają dziecku lek i dbają o jego zdrowie ${ }^{9}$. Jeśli chodzi o higienę i pielęgnację dzieci, to w starszych reklamach ${ }^{10}$ występowały wyłącznie mamy, natomiast obecnie w spotach ${ }^{11}$ pojawiają się także ojcowie, ale raczej jako asystenci czynności związane z pielęgnacją nadal są domeną mam ${ }^{12}$. Podobnie rzecz ma się w odniesieniu do żywności dla niemowląt ${ }^{13}$. Jeśli ojcowie pojawiają się w reklamach w kontekście tego typu czynności, to zazwyczaj jest to wzięte w nawias humoru ${ }^{14}$. Na zjawisko to wskazują też badacze reklamy (np. Arcimowicz, 2003; Leszczuk-Fiedziukiewicz, 2009), interpretując je jako wynikające z obawy przed nadmiernie odważnym kwestionowaniem utartych wzorców i stereotypów. Z tego modelu wyłamuje się niedawna

7 https://www.youtube.com/watch?v=Mbsbc9T_Am4 (dostęp: 10.06.2020); https:// www.youtube.com/watch?v=Oky-NY4fABM (dostęp: 10.06.2020); https://www.youtube. com/watch?v=6v0FXWXIlLw (dostęp: 10.06.2020).

${ }^{8}$ https://www.youtube.com/watch?v=KbM1A6N5S6E (dostęp: 10.06.2020).

${ }^{9}$ https://www.youtube.com/watch?v=k85dTXVbosg (dostęp: 10.06.2020); https:// www.youtube.com/watch?v=ia_PZEse594 (dostęp: 10.06.2020).

${ }^{10} \mathrm{https} / / /$ www.youtube.com/watch?v=O0M8yD9_ZrM (dostęp: 10.06.2020).

11 https://www.youtube.com/watch?v=hm0XkgtAS3Y (dostęp: 10.06.2020); https:// www.youtube.com/watch?v=vPwAq7SCE5M (dostęp: 10.06.2020).

${ }^{12}$ https://www.youtube.com/watch?v=tsDCmYKuzbE (dostęp: 10.06.2020).

${ }^{13}$ https://www.youtube.com/watch?v=Ysq0oRfhT_Q (dostęp: 10.06.2020); https:// www.youtube.com/watch?v=xhxWQe0x0lA (dostęp: 10.06.2020); https://www.youtube. com/watch?v=PeWuA2BtFNM (dostęp: 10.06.2020).

${ }^{14}$ https://www.youtube.com/watch?v=eptIimg96qk (dostęp: 10.06.2020). 
kampania Dove pod hasłem \#DadsCare, która pokazuje ojców podczas różnych codziennych czynności ${ }^{15}$. Kampania została rozpoczęta wiosną 2020 r. w związku z epidemią koronawirusa. W ramach kolejnych materiałów Dove we współpracy z różnymi ojcami przygotowywało materiały ze wskazówkami, jak zadbać o siebie i rodzinę w trakcie epidemii - jak uczyć dzieci gotować, jak dbać o higienę, jak wspierać dzieci w nauczaniu zdalnym itp. Nie była to zatem kampania reklamująca jakiś konkretny produkt (np. krem, żel, piankę do golenia itp.), ale nakierowana na budowanie wizerunku marki jako dostrzegającej ojców i wspierającej ich. Przykładem działania wizerunkowego w tym obszarze może być także zaproszenie przez markę DADA (producenta m.in. pieluszek i artykułów do pielęgnacji niemowląt) celebryty Rafała Maseraka do wywiadu na temat ojcostwa ${ }^{16}$. Analizując powyższe materiały, w najbliższych latach można się spodziewać wzrostu liczby reklam pokazujących ojców zaangażowanych w tego typu czynności, gdyż coraz większa ich liczba aktywnie uczestniczy w opiece nad dzieckiem od pierwszych dni jego życia (por. Baxter i in., 2016). Prawdopodobnie w pierwszej kolejności tego typu przekazy będą kierowane do mężczyzn o wyższym wykształceniu, zamieszkujących duże miasta, gdyż to wśród nich obserwuje się najszybsze tempo przemian w obrębie wzorców męskości i ojcostwa (Bierca, 2013).

O ojcach często mówi się, że czas, jaki spędzają z dziećmi, to głównie zabawa. Rzeczywiście, wyniki badań (Powrót taty, 2019; Włodarczyk, 2014) wskazują, że ojcowie sporo czasu przeznaczają na zabawę z dziećmi, więcej niż np. na wyjścia do kina, wspólne zakupy albo pomoc w nauce. Można by zatem przewidywać, że do tego obrazu ojca jako „doskonałego kompana do zabawy” będą odwoływać się kampanie reklamowe. Przykład takiego podejścia znajdujemy w reklamie Nintendo, zachęcającej do sprezentowania ojcom konsoli do gier. Hasłem reklamy jest „For Your Favorite Player 2"17 - odnosi się ono do tego, że do wielu gier potrzeba drugiego gracza, a tata może pełnić tę rolę i dostarczać dziecku rozrywki, ale potrzebuje do tego swojej konsoli. Ten kierunek, związany z reklamowaniem gadżetów elektronicznych, które umożliwią ojcu wspólne spędzanie czasu z dziećmi, może się nasilać, gdyż w nadchodzących latach ojcami coraz częściej będą zostawać młodzi mężczyźni, dla których wirtualna/elektroniczna rozrywka jest czymś, w czym sami dorastali.

\footnotetext{
15 https://www.youtube.com/watch?v=gw7GcdlNt_M (dostęp: 10.06.2020).

16 https://www.dadaclub.pl/dla-rodzicow/49/dobrze-byc-tata (dostęp: 2.12.2020).

17 https://www.youtube.com/watch?v=K8VBwyEWi_I (dostęp: 10.06.2020).
} 
Ostatnią ze stereotypowo ojcowskich (męskich) charakterystyk jest większe zapotrzebowanie na informację i kontrolę oraz dążenie do „eksperctwa”. Stereotypowo ukazuje się mężczyzn (ojców) jako bardziej racjonalnych, wyważonych - także w podejmowaniu decyzji. Potocznie przeciwstawia się czasem kompulsywne zachowania zakupowe kobiet z wykalkulowanymi decyzjami mężczyzn. Częściowo do tego wzorca odwołała się sieć Netto w kampanii pod hasłem „TatoWie”, podkreślając w tej nowej formie mnogiej (będącej alternatywą dla „ojcowie”) aspekt wiedzy, świadomości i kompetencji. Do tego odwołują się też poszczególne spoty reklamowe oraz materiały graficzne z tej kampanii - wskazują, że dobrze jest się znać na owocach $^{18}$, warzywach ${ }^{19}$ i, oczywiście, promocjach w danej sieci ${ }^{20}$. Obraz superojca, który na wszystkim się zna i potrafi zaradzić różnym rodzinnym trudnościom, a jednocześnie ma dystans i poczucie humoru, ukazuje również reklama płatków śniadaniowych Cheerios - „najlepszego przyjaciela ojca”21.

Przedstawiony powyżej przegląd koresponduje z wyłonionymi na podstawie psychografii postawami tzw. milenijnych ojców (Fromm i Vidler, 2015: 196), a te z kolei z klasyczną macierzą FCB dzielącą reklamy na cztery kategorie ze względu na zaangażowanie kupującego oraz dymensję „myślenie-odczuwanie” (Kall, 1999), do których należą:

- tata dostawca (ang. Provider dad) - to ojciec tradycyjny, który okazuje swoją miłość, dbając o rodzinę i wykonując „męskie” obowiązki w domu; do niego będą kierowane reklamy informacyjne produktów, w których zakup ojciec jest mocno zaangażowany i podczas których kieruje się przesłankami racjonalnymi (jak samochody, wyposażenie domu, polisy ubezpieczeniowe, np. reklama Nationale-Nederlanden);

- tata blender (ang. Blender dad) - to ojciec, który bierze większą odpowiedzialność za dzieci i dom, dzieli ten ciężar z mamą jest samotnym rodzicem lub częścią rodziny mieszanej; do tego ojca powinna być kierowana reklama tworząca „nowy” nawyk, która z założenia dotyczy produktów prozaicznych, kupowanych rutynowo (jak leki, środki do pielęgnacji niemowląt, żywność, np. reklama Oreo);

- tata społecznik (ang. Socializer dad) - to ojciec stawiający na kreatywność, utrzymujący równowagę między zajęciami fizycznymi i towarzyskimi;

18 https://www.youtube.com/watch?v=R1vPxiUmVsc (dostęp: 10.06.2020).

${ }^{19}$ https://www.youtube.com/watch?v=jsb_Kj3Ksi0 (dostęp: 10.06.2020).

${ }^{20} \mathrm{https}: / / w w w . y o u t u b e . c o m / w a t c h ? v=l p Z M c j D a P 5 I$ (dostęp: 10.06.2020).

${ }^{21} \mathrm{https}: / /$ www.youtube.com/watch?v=_HoPdhTUFjc\&feature=emb_logo (dostęp: 10.06.2020). 
dla tego ojca przeznaczona będzie reklama dająca satysfakcję, promująca produkty odzwierciedlające indywidualne upodobnia (jak zabawki, sprzęt elektroniczny, wydarzenia sportowe, np. reklama konsoli Nintendo);

- tata zdobywca (ang. Achiever dad) - ten ojciec priorytetyzuje znaczenie edukacji i zamożności we własnym życiu i przekazuje te wartości dzieciom; do tego ojca kierowana będzie reklama emocjonalna produktów, które są dla niego ważne, m.in. ze względu na wykreowanie wizerunku (jak zegarek, aparat fotograficzny, np. kampania Agencji Isobar Poland dla Fisher-Price $\mathrm{z}$ hashtagiem \#dumny tata ${ }^{22}$ ).

\section{Podsumowanie - dadvertising („marketing tacierzyński”)}

Celem niniejszego opracowania było: (1) przyjrzenie się temu, w jakim zakresie działania marketingowe kierowane są do ojców; (2) wskazanie możliwych przyczyn rzadszego kierowania kampanii reklamowych do ojców niż do matek; (3) scharakteryzowanie wizerunku taty obecnego w przekazach reklamowych; (4) zaproponowanie możliwych sposobów profilowania reklam, których głównymi adresatami są ojcowie, ze względu na specyfikę pełnienia przez nich roli rodzicielskiej.

Punktem wyjścia była konstatacja, że różnorodnych działań promocyjnych skierowanych do ojców jest mniej niż tych kierowanych do mam. Nie powstały dotąd usystematyzowane i pogłębione analizy dotyczące ojców jako adresatów przekazów reklamowych, w przeciwieństwie do istniejących opracowań uwzględniających matki (Solomon, 2009; Schor, 2004). Niniejszy tekst częściowo wypełnia wskazywaną przez badaczy (Raport z badań Matki 2013, 2013) lukę związaną z brakiem takich analiz. Jako możliwe przyczyny omawianego stanu rzeczy można wskazać funkcjonujące w naszym społeczeństwie stereotypy ról rodzinnych (Bakiera, 2014; Szulich-Kałuża i Wadowski, 2014; Wojciszke, 2002), realne różnice w zaangażowaniu ojców i matek w poszczególne czynności domowe i relację z dzieckiem (Endendijk i in., 2013; Powrót taty, 2019; Włodarczyk, 2014) oraz pewne aspekty prawne (Chełstowska i Zarzyńska, 2014), które sprawiają, że ojcom trudniej jest niekiedy spędzać czas ze swoimi dziećmi. Można przewidywać, że wraz ze zmianami we wspomnianych powyżej obszarach zmianie ulegać będzie także częstotliwość kierowania przekazów reklamowych do ojców.

${ }^{22}$ https://www.wirtualnemedia.pl/artykul/jak-ojciec-stal-sie-targetem-dla-reklamodawcow-i-mediow-analiza (dostęp: 28.12.2020). 
Odnosząc się do sposobu przedstawiania ojców w reklamach, należy podkreślić niejednorodność tego zjawiska. Zarówno kampanie przeanalizowane dla potrzeb niniejszego opracowania, jak i wnioski z podobnych analiz (zarówno w Polsce (np. Arcimowicz, 2003), jak i za granicą (np. Baxter i in., 2016)) wskazują na ścieranie się w przekazach reklamowych różnych wzorców realizowania roli ojcowskiej. Należy podkreślić, że na przestrzeni lat coraz częściej w przekazach tych uwzględniana jest więź łącząca ojca z dzieckiem. W najnowszych kampaniach (pochodzących z ostatnich kilku lat) aspekt relacyjny niekiedy staje się nawet głównym wątkiem w reklamie. Wobec zróżnicowanego i zmieniającego się sposobu przedstawiania tacierzyństwa w reklamach przyszłe badania mogłyby skupiać się na analizie odbioru tych przekazów przez samych ojców (por. Jasielska i Maksymiuk, 2018). Wnioski w tym zakresie mogłyby stanowić cenne źródło wiedzy zarówno dla marketerów, jak i badaczy z obszaru nauk społecznych zainteresowanych męską recepcją przemian we wzorcach życia rodzinnego.

Choć marketing nie jest odpowiedzialny za zmieniające się normy płci, to częściowo włącza się w proces negocjowania wzorców pełnienia roli ojcowskiej, mogąc niekiedy potęgować trudności, z którymi borykają się mężczyźni w tych zmieniających się czasach (Bakiera, 2014). Sami marketerzy również muszą uwzględniać te przemiany, gdyż sposób odbierania reklam, których bohaterami są ojcowie, jest związany z preferowanymi przez odbiorców wzorcami ról rodzinnych (Baxter i in., 2016) czy osobistymi doświadczeniami w relacji z ojcem (Cowart, 2019). Wydaje się, że bardziej egalitarne wzorce realizowania roli ojcowskiej mogą być korzystne z perspektywy marketerów, gdyż zakładają one, że także mężczyźni angażują się w opiekę nad dzieckiem i związane z tym zakupy. Można zatem przewidywać, że najbliższe lata przyniosą wzrost zainteresowania ojcami jako adresatami kampanii reklamowych.

W związku z tym podjęto też próbę zaproponowania możliwych sposobów „profilowania” przekazów reklamowych kierowanych do ojców. W świetle zebranych materiałów można stwierdzić, że najczęściej do ojców kierowane są reklamy dotyczące samochodów rodzinnych i przekazy zawierające „racjonalne argumentowanie” zalet danego produktu. Natomiast ogólnie, wydaje się, że ojcowie częściej są bohaterami kampanii społecznych (także połączonych ze zwiększaniem rozpoznawalności konkretnej marki) nakierowanych na wzmacnianie roli ojca niż adresatami reklam konkretnych produktów. Wydaje się, że tego typu działania mogą być pewną strategią firm - skierowaną na dokonywanie przemian na rynku reklamowym i na „miękkie”, na razie, pozyskiwanie ojców. Przedstawione powyżej, istniejące 
już, próby profilowania reklam tacierzyńskich wydają się uzasadnione, jeśli uwzględnić dane dotyczące sposobu realizowania roli ojcowskiej przez współczesnych mężczyzn. Uwzględniając jednak zachodzące w tym obszarze przemiany, warto wskazać na nowe obszary, których mogłyby dotyczyć reklamy i kampanie kierowane do ojców. Pierwszy z tych obszarów odnosi się do zaangażowania mężczyzn w okresie ciąży, porodu i połogu. Reklamy takie mogłyby dotyczyć zarówno produktów przeznaczonych dla partnerki (a więc bardziej związanych ze wspieraniem macierzyństwa), jak i kompletowania tzw. „wyprawki” lub przystosowania mieszkania do potrzeb powiększającej się rodziny (por. marketing kamieni milowych - Jasielska i Maksymiuk, 2011). W drugim obszarze, zważając na rosnące zaangażowanie mężczyzn w czynności opiekuńczo-pielęgnacyjne, mogą oni stać się bohaterami reklam środków do pielęgnacji niemowląt (np. kosmetyków) lub innych artykułów związanych z opieką nad małym dzieckiem (chusty, nosidełka). Odnosząc to do trendu czynienia z mężczyzn głównych adresatów reklam dotyczących samochodów, wydaje się, że reklamy nawiązujące do bezpiecznego transportu małych dzieci (np. fotelik samochodowy) mogłyby być adresowane do ojców. Ojcowie mogliby również stać się adresatami reklam dotyczących produktów finansowych związanych z bezpieczeństwem rodziny, a także różnych artykułów domowych. Pierwsza z propozycji odwołuje się do tradycyjnego, ale wciąż obecnego w społeczeństwie wzorca ojca jako odpowiedzialnego za utrzymanie rodziny. Druga natomiast koresponduje z rosnącym zaangażowaniem mężczyzn w zajmowanie się domem. Istotne wydaje się, że niezależnie od reklamowanego przedmiotu ważną komponentę profilowania przekazów reklamowych dla ojców powinno stanowić podkreślenie obiektywnych zalet produktu, wskazujących na „eksperctwo” potencjalnego nabywcy. Skuteczność takich działań mogłaby zostać zweryfikowana w badaniach eksperymentalnych.

Podsumowując analizę zebranych materiałów, warto podkreślić, że liczba reklam skierowanych do ojców (w tym tych, które ukazują ich w niestereotypowych rolach i aktywnościach) wzrasta na przestrzeni ostatnich lat. Można przewidywać, że ten trend będzie się nasilał wraz ze wzrostem popularności współczesnych, bardziej egalitarnych, inspirujących wzorców życia rodzinnego (Baxter i in., 2016). Należy ponadto podkreślić, że dadvertising ma korzenie w neoliberalnej polityce płci i aktywizmie towarowym, w których ewoluujące wzorce męskości są spersonalizowane i utowarowione w działania konsumpcyjne (Gentry i Harrison, 2010). Jest zatem prawdopodobne, że ojcowie i ich relacja z dziećmi staną się w najbliższym czasie obiektem bardziej intensywnych analiz ze strony działów marketingu i badaczy życia społecznego. 


\section{Literatura}

Arcimowicz, K. (2003). Obraz mężczyzny w polskich mediach. Prawda. Fałsz. Stereotyp. Gdańsk: Gdańskie Wydawnictwo Psychologiczne.

Bailey, M.T. (2008). Mom 3.0: Marketing With Today's Mothers by Leveraging New Media \& Technology. Deadwood: Wyatt-MacKenzie Publishing.

Bakiera, L. (2014). Mężczyzna w roli ojca. Psychospołeczne uwarunkowania zaangażowanego ojcostwa. W: B. Raszeja-Kotleba, M. Baranowska-Szczepańska (red.), On bez tajemnic. Problemy, analizy, perspektywy (ss. 41-58). Poznań: Instytut NaukowoWydawniczy MAIUSCULA.

Baxter, S.M., Kulczynski, A., Ilicic, J. (2016). Ads aimed at dads: Exploring consumers' reactions towards advertising that conforms and challenges traditional gender role ideologies. International Journal of Advertising, 35(6), 970-982. https://doi.org/10. 1080/02650487.2015.1077605.

Bell, J. (2013). Putting dad in the picture: Fatherhood in the popular women's magazines of 1950s Australia. Women's History Review, 22(6), 904-929. https://doi.org/10.108 0/09612025.2013.780843.

Bierca, M. (2013). Tacierzyństwo w sieci - analiza nowego trendu i jego socjologiczne implikacje. InterAlia. Pismo Poświęcone Studiom Queer, 8, 79-90.

Chang, C.T., Tung, M.H. (2015). Intergenerational appeal in advertising: Impacts of brandgender extension and brand history. International Journal of Advertising, 35(2), 345-361. https://doi.org/10.1080/02650487.2015.1030282.

Chełstowska, A., Zarzyńska, A. (2014). Urlopy dla ojców w kontekście różnych modeli polityki rodzinnej w Europie. Instytut Spraw Publicznych. http://rownoscplci.pl/ uploads/pdf/832753405.pdf (dostęp: 10.06.2020).

Cowart, K.O. (2019). Daddy Dearest: The influence of paternal investment on attitude toward the advertisement. Journal of Advertising, 49(2), 1-11. https://doi.org/10.10 80/00913367.2019.1696721.

Duhigg, Ch. (2013). Siła nawyku. Dlaczego robimy to, co robimy i jak można to zmienić w życiu i biznesie. Warszawa: Dom Wydawniczy PWN.

Endendijk, J.J., Groeneveld, M.G., Berkel van, S.R., Hallers-Haalboom, E.T., Mesman, J., Bakermans-Kranenburg, M.J. (2013). Gender stereotypes in the family context: Mothers, fathers, and siblings. Sex Roles, 68(9-10), 577-590.

Fein, R.A. (1978). Research on fathering: Social policy and an emergent perspective. Journal of Social Issues, 34(1), 122-135.

Fromm, J., Vidler, M. (2015). Millennials with Kids: Marketing to This Powerful and Surprisingly Different Generation of Parents. New York: American Management Association.

Gentry, J., Harrison, R. (2010). Is advertising a barrier to male movement toward gender change? Marketing Theory, 10(1), 74-96. https://doi.org/10.1177/1470593109355246.

Gospodarstwa domowe i rodziny. Charakterystyka demograficzna. Narodowy Spis Powszechny Ludności i Mieszkań 2011 (2014). Warszawa: Główny Urząd Statystyczny.

Gurba, E. (2009). Wczesna dorosłość. W: B. Harwas-Napierała, J. Trempała (red.), Psychologia rozwoju człowieka. Charakterystyka okresów życia człowieka (ss. 202-233). Warszawa: Wydawnictwo Naukowe PWN. 
Halawa, M. (2006). Komercjalizacja dzieciństwa. Kosztorysowanie rodzicielstwa. W: M. Bogunia-Borowska (red.), Dziecko w świecie mediów i konsumpcji (ss. 45-55). Kraków: Wydawnictwo Uniwersytetu Jagiellońskiego.

Havighurst, R.J. (1981). Developmental Tasks and Education. New York: LONGMAN.

Ho, T.H., Lim, N., Camerer, C.F. (2006). How „psychological” should economic and marketing models be. Journal of Marketing Research, 43(3), 341-344.

Hochschild, A. (1989). The Second Shift. New York: Avon Books.

Janowicz, K. (2017). Współczesne ojcostwo w oczach młodych bezdzietnych kobiet i mężczyzn. W: A. Łukasik, K. Węgrzyn-Białogłowicz, A. Englert-Bator (red.), Kobiety i mężczyźni. Różnice, podobieństwa (ss. 238-253). Rzeszów: Wydawnictwo Uniwersytetu Rzeszowskiego.

Janowicz, K. (2018). Sex differences in vision of own parenthood in late adolescence and early adulthood. Referat wygłoszony podczas 9th Congress of European Society on Family Relations. Organizator: European Society on Family Relations. Porto, 4-8.09.2018.

Jasielska, A., Maksymiuk, R.A. (2010a). Dorośli reklamujq, dzieci kupują. Kindermarketing i psychologia. Wydawnictwo Naukowe Scholar.

Jasielska, A., Maksymiuk, R.A. (2010b). Wpływ infantylizacji kultury na zmiany w społeczeństwie konsumpcyjnym. Kultura i Społeczeństwo, 54(2), 5-20.

Jasielska, A., Maksymiuk, R.A. (2011). Skomercjalizowane rodzicielstwo - nowy aspekt współczesnej dorosłości. Psychologia Rozwojowa, 16(2), 33-49.

Jasielska, A., Maksymiuk, R.A. (2018). Dla kogo Brand Hero? O wpływie bohatera marki dziecięcej na intencje zakupowe osób dorosłych. Człowiek i Społeczeństwo, 45, 169-198.

Jaworowski M.J., Polański P. (2004). Trendy społeczne i konsumenckie w Polsce u progu Unii Europejskiej. Referat wygłoszony podczas V Ogólnopolskiego Kongresu Badaczy Rynku i Opinii. Warszawa, 21-22.10.2004.

Kall, J. (1999). Reklama. Warszawa: Polskie Wydawnictwo Ekonomiczne.

Kłosińska, K. (2015). Rodzic jako znak naszych czasów. Poradnik Językowy, 5, 95-101.

Kwaśniewski, T., Masłowski, J. (2016). Czasem czuły, czasem barbarzyńca. Warszawa: Wydawnictwo Agora.

Leader, C.F. (2019). Dadvertising: Representations of fatherhood in Procter \& Gamble's TIDE commercials. Communication, Culture and Critique, 12, 72-89. https://doi. org/10.1093/ccc/tcz002.

Leszczuk-Fiedziukiewicz, A. (2009). Rodzina w polskiej reklamie telewizyjnej po przełomie 1989 roku. Toruń: Dom Wydawniczy DUET.

Lewandowski, G. (2007). Fenomen alfamamy. Marketing przy kawie. http://www.marketingnews.pl/article.php?art=1137 (dostęp: 12.11.2020).

Liberska, H., Matuszewska, M. (2014). Modele funkcjonowania rodziny. Style wychowania. W: I. Janicka, H. Liberska (red.), Psychologia rodziny (ss. 115-139). Warszawa: Wydawnictwo Naukowe PWN.

Maher, J.M., Dever, M., Curtin, J., Singleton, A. (2004). What Women (and Men) Wants: Births, Policies and Choices. Melbourne: School of Political and Social Inquiry.

Marshall, D., Davis, T., Hogg, M.K., Schneider, T., Petersen, A. (2014). From overt provider to invisible presence: Discursive shifts in advertising portrayals of the father in Good Housekeeping, 1950-2010. Journal of Marketing Management, 30(15-16), 1654-1679. https://doi.org/10.1080/0267257X.2014.945471. 
Marsiglio, W., Hutchinson, S., Cohan, M. (2000). Envisioning fatherhood: A social psychological perspective on young men without kids. Family Relations, 49, 133-142.

Ostoja-Zawadzka, K. (1997). Cykl życia rodzinnego. W: B. de Barbaro (red.), Wprowadzenie do systemowego rozumienia rodziny (ss. 18-30). Kraków: Wydawnictwo Uniwersytetu Jagiellońskiego.

Powrót taty. Polskie ojcostwo: pełen etat czy praca dorywcza? (2019). Nationale Nederlanden. https://media.nn.pl/61309-powrot-taty-polskie-ojcostwo-pelen-etat-czypraca-dorywcza (dostęp: 10.06.2020).

Raport Czy nowe technologie wychowujq dzieci Milenialsów? (2016). SW Research.

Raport Family Power. IQS Research Think Forward.

Raport z badań Matki 2013. (2013). Maison \& Partners.

Rejowska, A. (2015). Wizerunek ojcostwa w polskiej reklamie telewizyjnej. Dyskursy Młodych Andragogów, 16, 353-367.

Rydz, S. (2014). Samotne rodzicielstwo. W: I. Janicka, H. Liberska (red.). Psychologia rodziny (ss. 243-258). Warszawa: Wydawnictwo Naukowe PWN.

Schor, J. (2004). Born to Buy: The Commercialized Child and the New Consumer Culture. New York: Scribner.

Sewera, I. (2013). Gwiazdka dla matki z pokolenia Y. https://marketingprzykawie.pl/artykuly/ gwiazdka-dla-matki-z-pokolenia-y/ (dostęp: 12.11.2020).

Siegel, D., Coffey, T., Livingson, G. (2005). Marketing to the New Super Consumer: Mom \& Kid. Rochester: Paramount Market Publishing, Inc.

Solomon, M.R. (2009). Consumer Behavior. Buying, Having, and Being. $8^{\text {th }}$ Ed. New Delhi: Dorling Kindersley licensed of Pearson Education in South Asia.

Szlendak, T. (2005). Leniwe maskotki, rekiny na smyczy. W co kultura konsumpcyjna przemieniła mężczyzn i kobiety. Warszawa: Wydawnictwo Jacek Santorski \& Co Agencja Wydawnicza.

Szpak, D. (2019). Momfluencerki w sieci. Jak zbudować z nimi autentyczną relację jako marka? https://marketingprzykawie.pl/artykuly/momfluencerki-sieci-zbudowac-nimiautentyczna-relacje-jako-marka/ (dostęp: 12.11.2020).

Szulich-Kałuża, J., Wadowski, D. (2014). Tendencje przemian ojcostwa i roli ojca we współczesnym społeczeństwie. W: D. Kornas-Biela (red.), Ojcostwo dzisiaj (ss. 53-74). Lublin: Fundacja Cyryla i Metodego.

Tian, K. (2019). The influence of cultural orientation on gender role representations: Horizontal-vertical values in cross-cultural advertising. International Journal of Business Anthropology, 7(1), 49-84. https://doi.org/10.33423/ijba.v7i1.1108.

Tsai, W.S. (2010). Family man in advertising? A content analysis of male domesticity and fatherhood in Taiwanese commercials. Asian Journal of Communication, 20(4), 423-439. https://doi.org/10.1080/01292986.2010.496860.

Virani, A., Duffett-Leger, L., Letourneau, N. (2019). Parenting apps review: In search of good quality apps. mHealth, 5, 44. https://doi.org/10.21037/mhealth.2019.08.10.

Włodarczyk, J. (2014). Być tatą. Wyniki badania polskich ojców. Dziecko krzywdzone. Teoria, Badania, Praktyka, 13(3), 94-138.

Wojciszke, B. (2002). Kobiety i mężczyźni: odmienne spojrzenie na różnice. Gdańsk: Gdańskie Wydawnictwo Psychologiczne. 